\title{
Pemaknaan Bank Sampah Galang Panji sebagai Media Pendidikan Karakter dalam Pembelajaran IPS
}

\author{
Tini Agustini ${ }^{*}$, Nengah Bawa Atmadja², Wayan Mudana ${ }^{3}$ \\ 1 Program Studi Pendidikan IPS, Program Pasca Sarjana Universitas Pendidikan Ganesha Singaraja \\ 2 Program Studi Pendidikan IPS, Program Pasca Sarjana Universitas Pendidikan Ganesha Singaraja. \\ 3 Program Studi Pendidikan IPS, Program Pasca Sarjana Universitas Pendidikan Ganesha Singaraja..
}

\begin{abstract}
Abstrak
Tujuan penelitian ini adalah mendeskripsikan: (a) hal-hal yang melatarbelakangi Bank Sampah Galang Panji dilihat dari perspektif ilmu-ilmu sosial, (b) sistem pengelolaan Bank Sampah Galang Panji, dan (c) pengimplementasian Bank Sampah Galang Panji sebagai media pendidikan karakter dalam pembelajaran IPS di SMP Negeri 4 Singaraja. Jenis penelitian ini adalah penelitian kualitatif. Lokasi penelitian adalah Desa Panji, Kecamatan Sukasada, Kabupaten Buleleng, Provinsi Bali. Adapun informan kunci penelitian ini adalah: pendiri dan sekaligus Manager Bank Sampah Galang Panji, tokoh masyarakat Panji, nasabah bank sampah, guru dan siswa SMPN 4 Singaraja. Dalam penelitian ini sampel penelitian ditentukan berdasarkan teknik purposive sampling. Pada kegiatan wawancara dalam rangka pengumpulan data, informan kunci diperluas dengan teknik snowball. Metode pengumpulan data yang digunakan dalam penelitian ini adalah wawancara, observasi, kuesioner, dan studi dokumentasi. Data dianalisis secara kualitatif dengan mengikuti beberapa tahapan seperti reduksi data, menyajikan, menafsirkan, dan menarik kesimpulan. Hasil penelitian menunjukkan bahwa (1) secara historis cikal bakal berdirinya Bank Sampah Galang Panji berasal dari dua orang pemuda Dusun Kelod Kauh, Desa Panji yang bergabung dalam Pemuda Peduli Lingkungan Bali (PPLB) dan melalui perjuangan yang gigih akhirnya pada bulan Oktober 2014 Bank Sampah yang diberi nama Bank Sampah Galang Panji berdiri secara resmi, (2) Bank Sampah Galang Panji dikelola oleh pengurus yang ditetapkan dengan Surat Keputusan Kepala Dinas Kebersihan dan Pertamanan Kabupaten Buleleng dan didukung oleh Surat Keputusan Perbekel Desa Panji; yang mana pengelolaan Bank Sampah Galang Panji dilakukan secara sederhana karena tidak memiliki deskripsi tugas, dewan pengawas, serta anggaran dasar dan anggaran rumah tangga, dan (3) pengimplementasian Bank Sampah Galang Panji sebagai media pendidikan karakter dalam pembelajaran IPS di SMPN 4 Singaraja dilakukan secara terintegrasi, terdapat enam strategi yang dapat dilakukan untuk pengimplemenntasian bank sampah sebagai media pendidikan karakter.
\end{abstract}

\author{
Keywords: \\ Kata-kata kunci: bank \\ sampah, media, \\ pendidikan karakter
}

\section{PENDAHULUAN}

Sampah adalah suatu bahan yang terbuang atau dibuang dari sumber hasil aktivitas manusia maupun proses alam yang belum memiliki nilai ekonomis (Ecolink dalam Sukatman,dkk., 1998). Sulistyorini (2005) dan Anggraini (2012) menyatakan bahwa sampah (refuse) adalah sebagian dari sesuatu yang tidak dipakai, tidak disenangi atau sesuatu yang harus dibuang, yang umumnya berasal dari kegiatan yang dilakukan oleh manusia (termasuk kegiatan industri), tetapi bukan biologis (karena human waste tidak termasuk didalamnya) dan umumnya bersifat padat Sampah adalah sesuatu yang tidak berguna lagi, dibuang oleh pemiliknya atau pemakai semula (Tandjung dalam Sukatman,dkk.,1998). Sampah organik dan anorganik dapat menimbulkan permasalahan lingkungan apabila tidak ditangani dengan baik. Apalagi sampah anorganik yang sangat sulit dan memerlukan waktu yang sangat lama untuk dapat diuraikan secara alami. Sampah anorganik memerlukan pengelolaan khusus. Menurut Wahyono (2001) Sampah organik mengandung berbagai macam zat seperti karbohidrat, protein, lemak, mineral, vitamin, dsb. Secara alami, zat-zat tersebut mudah terdekomposisi oleh pengaruh fisik, kimia, enzim yang dikandung oleh sampah itu sendiri dan enzim yang dikeluarkan oleh organisma yang hidup di dalam

* Corresponding author.

E-mail Addresses: - dalbo_manik@yahoo.com (Tini Agustini) 
sampah. Inilah yang dilakukan oleh Bank Sampah Galang Panji, sehingga sampah anorganik seperti plastik, kaleng bekas, besi rongsokan, dan lain-lain dikelola melalui suatu manajemen tertentu yang dapat mensejahterakan masyarakat dan berdampak kepada kelestarian lingkungan.

Laju produksi sampah terus meningkat, tidak saja sejajar dengan laju pertumbuhan penduduk tetapi juga sejalan dengan meningkatnya pola konsumsi masyarakat (Riswan, 2011). Keberadaan sampah yang tidak dikelola dapat mengakibatkan pencemaran lingkungan. Apalagi pola hidup masyarakat yang tidak peduli lingkungan seperti membuang sampah sembarangan dapat menyebabkan pendangkalan aliran sungai, pencemaran sumber air, dan pemicu banjir. Kebiasaan mencampurkan sampah kering dan basah, sampah organik dan anorganik berdampak semakin sulit pengelolaan dan penanganan sampah. Subaris dan Endah (2016) mengemukakan bahwa pengelolaan sampah merupakan hal yang penting untuk diperhatikan jika tidak ingin wilayah akan menjadi lautan sampah. Pengelolaan sampah dengan cara me-milah sampah sesuai jenisnya sebenarnya sudah berjalan dengan baik, namun kurangnya pengetahuan masyarakat akan pengolahan sampah organik menjadikan pengelolaan sampah ini tidak berjalan efektif sehingga banyak terjadi penum-pukan sampah organik.Hal yang dilakukan oleh para pemuda pendiri (Yuniwati, 2012 dan Riyanto, 2015). Bank Sampah Galang Panji untuk memberdayakan masyarakat dalam penciptaan lingkungan yang bersih dan sehat patut diacungi jempol. Keberadaan Bank Sampah Galang Panji tampaknya perlu dikaji dari perspeftif ilmu-ilmu sosial seperti sejarah, ekonomi, budaya, geografi, dan lain-lain.

Bank Sampah Galang Panji memiliki keunikan tertentu. Bank sampah ini dirintis dan dilaksanakan oleh para pemuda Dusun Kelod Kauh, Desa Panji, Kecamatan Sukasada. Pada umumnya para pemuda jaman sekarang memiliki rasa cuek dan ketidakpedulian terhadap kebersihan lingkungan. Mereka biasanya sibuk dengan berbagai kegiatan persekolahan, les privat, menyalurkan hobi, nongkrong, bersosialita di media sosial, jalan-jalan, main game online, dan berbagai kegiatan lainnya. Berbeda dengan pemuda pada umumnya, para pemuda perintis Bank Sampah Galang Panji rela mengorbankan waktu dan tenaga untuk berkecimpung dalam kegiatan penuh pengabdian mendirikan dan mengelola bank sampah.

Berbicara tentang bank sampah tidak akan terlepas dari istilah manajemen karena bank sampah merupakan suatu lembaga atau unit usaha yang memerlukan sistem manajerial. Dalam melaksanakan suatu kegiatan yang berhubungan dengan manajemen, maka akan berkaitan dengan teori manajemen. Intelektual Perancis Pierre Bourdieu melihat manajemen sebagai social field, yaitu sebuah arena sosiokulkural yang spesifik dimana aktor tertentu bermain dalam menciptakan konstruksi dan transformasi sosial.

Teori manajemen bisa dipahami sebagai sebuah proses sosial dan figure sosial. Sebagai proses sosial, teori manajemen adalah proses bagaimana organisasi bisa berjalan secara efektif dan efisien. Sebagai figur sosial, teori manajemen adalah kelompok sosial, biasanya terdiri dari eksekutif dan manajer, yang bekerja untuk menciptakan efektivitas dan efisiensi organisasi demi mencapai tujuan organisasi.

Keberadaan Bank Sampah Galang Panji dapat dijadikan salah satu media pendidikan karakter bagi para siswa SMP. Keberadaan para pemuda dibalik pendirian dan pengelolaan bank sampah dapat menjadi inspirasi dan suri teladan bagi siswa SMP. Untuk itu perlu dikaji strategi-strategi pemanfaatan bank sampah sebagai media pendidikan karakter. Terdapat beberapa hal menarik yang perlu dikaji lebih mendalam tentang Bank Sampah Galang Panji. Pertama, hal-hal yang melatarbelakangi Bank Sampah Galang Panji dilihat dari perspektif ilmu-ilmu sosial. Kedua, sistem pengelolaan sampah yang dilakukan Bank Sampah Galang Panji. Ketiga, pengimplementasian Bank Sampah Galang Panji sebagai media pendidikan karakter dalam pembelajaran IPS di SMP.

\section{METODE PENELITIAN}

Metode penelitian yang digunakan adalah metode penelitian kualitatif dengan mendekatkan pada teknik-teknik pendekatan kualitatif. Lokasi penelitian adalah Desa Panji, Kecamatan Sukasada, Kabupaten Buleleng, Provinsi Bali. Informan penelitian iniadalah para pemuda pendiri dan pengelola bank sampah, tokoh-tokoh masyarakat, kepala desa, kepala dusun, nasabah bank sampah, guru dan siswa SMPN 4 Singaraja. Dalam penelitian ini sampel penelitian ditentukan berdasarkan teknik purposive sampling. Pada kegiatan wawancara dalam rangka pengumpulan data, informan kunci diperluas dengan teknik snowball. Sesuai dengan jenis penelitian ini yaitu penelitian kualitatif, maka metode pengumpulan data yang digunakan dalam penelitian ini adalah wawancara, observasi, kuesioner, dan studi dokumentasi. Data yang diperoleh dari berbagai informan melalui wawancara, observasi, pencatatan dokumen, dan kuesioner kemudian diolah, diverifikasi sehingga diperoleh data yang objektif mengenai hal-hal yang melatarbelakangi pendirian bank sampah, sistem pengelolaan bank sampah, dan pengimplementasian bank sampah sebagai media pendidikan karakter dalam pembelajaran IPS di SMP. Dalam penelitian ini digunakan dua triangulasi, yaitu triangulasi data dan triangulasi metode. Pada penelitian kualitatif analisis 
data dilakukan pada saat pengumpulan data dan setelah pengumpulan data dalam kurun waktu tertentu. Analisis data dilakukan mengan mengikuti beberapa tahapan seperti reduksi data, menyajikan, menafsirkan, dan menarik kesimpulan.

\section{ANALISIS DAN PEMBAHASAN}

Latar belakang berdirinya Bank Sampah Galang Panji ditinjau dari perspektif ilmu sosial sangat kompleks. Pespektif ilmu sosial yang digunakan dalam penelitian ini ada tiga, yakni sejarah, ekonomi, dan budaya. Keterbatasan perspektif ilmu sosial yang digunakan dalam penelitian ini disebabkan oleh keterbatasan waktu dan biaya penelitian.

Ditinjau dari perspektif sejarah atau historis, ternyata cikal bakal berdirinya Bank Sampah Galang Panji berasal dari dua orang pemuda Dusun Kelod Kauh, Desa Panji, Kecamatan Sukasada. Kedua pemuda tersebut adalah Gede Ganesha dan Nyoman Marsa Jaya. Keduanya memiliki karakter yang sama, yakni mencintai lingkungan hidup. Berdasarkan karakter tersebut, Gede Ganesha dan Nyoman Marsa Jaya ikut bergabung dalam suatu organisasi pemuda pecinta lingkungan. Organisasi tersebut adalah Pemuda Peduli Lingkungan Bali (PPLB) yang berdiri pada tanggal 16 Agustus 2012.

Keterlibatan dua orang pemuda Panji dalam aktivitas PPLB sebagai penceramah dan motivator di berbagai tempat tentang kebersihan dan pelestarian lingkungan menuntut keduanya menjadi suri teladan bagi pemuda lain dari berbagai desa di Kabupaten Buleleng. Keberadaan mereka sebagai aktivis PLPB menimbulkan kegundahan dan rasa malu karena desa mereka sendiri, Desa Panji, keadaan lingkungannya masih kotor dan jorok. Akhirnya kedua pemuda tersebut memutar otak dan merencanakan aksi sosial agar dapat tercipta lingkungan yang bersih, asli, dan lestari.

Melalui pengalaman terlibat dalam kegiatan-kegiatan PLPB, kedua pemuda mengenal bank sampah. Bagi mereka, solusi yang tepat untuk memecahkan permasalahan sampah di Desa Panji adalah mendirikan sebuah bank sampah. Pertama-tama kedua pemuda tersebut mengadakan pendekatan dan sosialisasi kepada para pengurus dan anggota Sekaa Teruna Satya Warga, Banjar Kelod Kauh, Desa Panji, Kecamatan Sukasada. Mengingat kedua pemuda ini adalah pemuda teladan dan dipercaya oleh temanteman di kalangan Sekaa Teruna Satya Warga, maka keinginan untuk mendirikan Bank Sampah akhirnya disambut baik oleh para pemuda. Berkat dukungan dari para pemuda, perbekel Desa Panji, dan juga pemerintah Kabupaten Buleleng, akhirnya pada bulan Oktober 2014 Bank Sampah yang diberi nama Bank Sampah Galang Panji berdiri secara resmi.

Bank Sampah adalah organisasi sosial kemasyarakatan yang merupakan unit aksi, dengan aksi sosial atau voluntarisme yang menyangkut perbuatan yang dilakukan oleh satu atau beberapa pelaku. Pada dasarnya bank sampah merupakan konsep pengumpulan sampah kering dan dipilah serta memiliki manajemen layaknya perbankan,tetapi yang ditabung bukan uang melainkan sampah (Ateria, 2016). Oleh karena itu, aksi sosial atau voluntaristik mencakup unsur-unsur dasar: (1) pelaku, yang merupakan pribadi individual, (2) pelaku mencari tujuan-tujuan yang akan dicapai, (3) pelaku mempunyai cara-cara untuk mencapai tujuan, (4) pelaku dihadapkan pada pelbagai kondisi situasional, (5) pelaku dikuasai oleh nilai-nilai, kaidah-kaidah, dan gagasan-gagasan lain yang mempengaruhi penetapan tujuan dan pemilihan cara untuk mencapai tujuan, dan (6) aksi mencakup pengambilan keputusan secara subjektif oleh pelaku untuk memilih cara mencapai tujuan, yang dibatasi oleh berbagai gagasan dan kondisi situasional (Parsons dalam Soekanto, 1986). Para pemuda Dusun Kelod Kauh, Desa Panji sebagai pelaku Bank Sampah Galang Panji melakukan cara-cara tertentu untuk mencapai tujuan yang diharapkan demi keberlangsungan bank sampah. Dalam melakukan cara-cara untuk mencapai tujuan akan dipengaruhi oleh kaidah-kaidah, nilai-nilai, dan gagasan-gagasan lain serta dihadapkan pada kondisi-kondisi situasional di lapangan.

Sejak berdiri tahun 2014, bank sampah ini mengalami perkembangan yang menggembirakan. Ternyata dengan adanya bank sampah ini dapat memberikan dampak ekonomi yang positif berupa penghasilan tambahan bagi masyarakat Desa Panji. Informasi dari mulut ke mulut, media sosial serta media cetak dan elektronik tentang Bak Sampah Galang Panji menjadikan bank sampah ini semakin dikenal dan berkembang di masyarakat. Masyarakat Desa Panji merasakan keuntungan ekonomi berkat adanya bank sampah. Sampah yang semula dibuang sembangan, dapat merusak kelestarian lingkungan. Sampah anorganik seperti plastik dan logam dapat mencemari lingkungan karena susah diuraikan oleh mikro organisme. Untuk mengatasi hal ini ini, maka sampah-sampah dipilah untuk dijual pada Bank Sampah Galang Panji, sehingga masyarakat memperoleh tambahan penghasilan. Keberadaan bank sampah ini dapat memberi nilai pendidikan kepada masyarakat berupa kegiatan gemar menabung.

Selain dari segi sejarah dan ekonomi, keberadaan Bank Sampah Galang Panji juga dapat dilihat dari perspektif budaya. Budaya merupakan suatu cara hidup yang berkembang dan dimiliki bersama oleh sebuah kelompok orang, dan diwariskan dari generasi ke generasi. Sebagian masyarakat Panji memiliki 
budaya hidup bersih dan sebagian lagi sebaliknya. Keberadaan bank sampah ternyata mampu mengubah pola hidup masyarakat dari semula cuek masalah sampah menjadi peduli terhadap sampah dan dari malas memilah sampah menjadi rajin memilah sampah. Pola hidup masyarakat yang berubah sebagaimana contoh tersebut mengindikasikan bahwa bank sampah telah berkontribusi mengubah budaya masyarakat ke arah yang lebih baik.

Pengelolaan Bank Sampah Galang Panji dilakukan oleh pengurus yang ditetapkan dengan Surat Keputusan Kepala Dinas Kebersihan dan Pertamanan Kabupaten Buleleng dan didukung oleh Surat Keputusan Perbekel Desa Panji. Pengurus Bank Sampah Galang Panji terdiri atas Donatur/Pelindung, Direktur/Ketua, Direktur Operasional yang dibantu oleh Koordinator Bidang Pengambilan, Koordinator Bidang Pemilahan, dan Koordinator Bidang Relawan, Direktur Keuangan, Staf Administrasi, dan Staf Kegiatan Pengembangan. Struktur Kepengurusan telah dimiliki oleh Bank Sampah Galang Panji.

Berdasarkan struktur kepengurusan diketahui bahwa Direktur/Ketua Bank Sampah Galang Panji dijabat secara ex officio oleh Kepala Dusun Kelod Kauh. Koordinator Bidang Relawan dijabat secara kolegial oleh Sekaa Teruna Satya Warga Banjar Adat Kelod Kauh, Desa Panji, Kecamatan Sukasada. Berdasarkan hasil kajian, ternyata kepengurusan Bank Sampah Galang Panji memiliki beberapa kelemahan. Pertama, dalam kepengurusan tidak ada sistem pengawasan dan tidak memiliki dewan pengawas. Tanpa adanya pengawasan terhadap pengelolaan bank sampah, maka kemungkinan penyimpangan pengelolaan dan penggunaan dana bank sampah bisa saja tidak terdeteksi dan terpantau. Hal ini dapat berdampak terhadap keberlangsungan bank sampah tersebut. Kedua, Bank Sampah Galang Panji tidak memiliki anggaran dasar dan anggaran rumah tangga. Ketiadaan anggaran dasar dan aggaran rumah tangga dapat berdampak terhadap jalannya bank sampah yang tidak memiliki aturan dan mekanisme kerja yang baik. Ketiga, bank sampah ini tidak memiliki deksripsi tugas yang spesifik. Deskripsi tugas yang yang umum perlu dilengkapi dengan deskripsi tugas yang lebih khusus, sehingga tidak akan terjadi tumpang tindih pekerjaan dan saling lempar tanggung jawab.

Istilah manajemen berasal dari bahasa Italia "maneggiare" berarti "mengendalikan". Dalam bahasa Perancis manajemen berasal dari kata "management" yang berarti "seni melaksanakan dan mengatur". Pengaturan yang dilakukan melalui proses aktivitas dan diatur berdasarkan urutan dan fungsinya dinamakan manajemen (Effendi, 2015). Menurut Gibson, dkk. (1996) sifat pekerjaan manajemen ialah mengkoordinasikan pekerjaan orang lain dengan melaksanakan empat fungsi manajemen yaitu perencanaan, pengorganisasian, pengarahan, dan pengontrolan (planning, organizing, directing, and controlling). Fungsi-fungsi manajemen belum secara optimal diterapkan dalam pengelolaan Bank Sampah Galang Panji.

Berdasarkan keberadaan peserta didik dan lingkungan, strategi pengimplentasian bank sampah sebagai media pendidikan karakter dalam pembelajaran IPS di SMP dapat dibagi dua, yakni (1) peserta didik diajak secara bersama-sama berkunjung ke bank sampah dan (2) membawa bagian lingkungan kepada peserta didik. Cara pertama dapat dilakukan dengan tiga strategi, yaitu: (1) siswa diajak bersamasama berkunjung ke lokasi bank sampah melalui metode karya wisata; (2) siswa diberi tugas kelompok untuk membuat laporan kunjungan ke bank sampah; dan (3) secara berkelompok siswa diberi proyek membuat video tentang bank sampah. Selanjutnya cara kedua dapat dilakukan dengan tiga strategi, yakni (1) memanfaatkan media video pembelajaran tentang bank sampah, (2) memanfaatkan media foto tentang aktivitas para pemuda dalam menjalankan tugas pengelolaan bank sampah, dan (3) guru mengundang narasumber salah seorang pemuda pendiri bank sampah untuk memberikan materi di kelas tentang bank sampah. Dengan demikian terdapat enam strategi pengimplementasian Bank Sampah Galang Panji sebagai media pendidikan karakter dalam pembelajaran IPS di SMP.

Melalui kuesioner para guru mengemukakan bahwa strategi yang paling mudah diterapkan, paling sesuai diterapkan di SMPN 4 Singaraja, dan berpusat pada siswa adalah strategi berkunjung ke lokasi bank sampah melalui metode karya wisata. Hal ini senada dengan yang diungkapkan oleh para siswa bahwa staregi berkunjung ke lokasi bank sampah merupakan strategi yang paling memotivasi, sesuai dengan keinginan siswa, menarik perhatian siswa, dan mengaktifkan siswa dalam pembelajaran. Pengalaman langsung dan riil, pemahaman yang lebih mudah, serta mudah dilakukan menjadi alasan guru dan siswa memilih metode karya wisata untuk mempelajari bank sampah. Lokasi Bank Sampah Galang Panji yang tidak terlalu jauh dari SMPN 4 Singaraja (lebih kurang $3 \mathrm{Km}$ ) dan banyaknya siswa SMPN 4 Singaraja yang berasal dari Panji barangkali menjadi pertimbangan lain mereka memilih strategi ini.

Selanjutnya bagi guru dan siswa strategi yang paling sulit dilakukan adalah pemberian tugas kelompok untuk membuat film dokumenter/video tentang bank sampah. Alasan yang dikemukakan oleh mereka adalah keterampilan pembuatan video rendah, sarana kurang mendukung, dan membutuhkan waktu yang banyak, serta biaya yang besar dalam meproduksi film atau video tentang bank sampah.

Pendidikan karakter dimaknai sebagai pendidikan yang mengembangkan nilai-nilai karakter pada peserta didik sehingga mereka memiliki nilai dan karakter sebagai dirinya, menerapkan nilai-nilai 
tersebut dalam kehidupan dirinya, sebagai anggota masyarakat dan warga negara yang religious, nasionalis, produktif, dan kreatif (Zubaedi, 2011:17). Secara garis besar nilai dibagi dalam dua kelompok yaitu nilai nurani dan nilai memberi. Nilai nurani merupakan nilai yang bersumber dari dalam diri manusia yang berkembang menjadi perilaku seseorang dan cara bagaimana memperlakukan seseorang. Yang masuk ke dalam hati nurani, misalnya kejujuran, keberanian, cinta damai, disiplin, tahu diri, dan lain sebagainya. Nilai memberi yaitu nilai yang dipraktikkan atau diberikan yang kemudian diterima sebanyak yang diberikan. Seperti setia, dapat dipercaya, dihormati, cinta kasih, baik hati, ramah, dan lain sebagainnya (Elmubarok, 2009).

Pendidikan karakter merupakan suatu sistem penanaman nilai-nilai karakter kepada warga sekolah yang meliputi komponen pengetahuan, kesadaran atau kemauan dan tindakan untuk melaksanakan nilai-nilai tersebut baik dalam hubungannya dengan Tuhan Yang Maha Esa (TYME), diri sendiri, sesama, lingkungan, maupun kebangsaan, sehingga menjadi manusia seutuhnya (manusia Pancasilais). Pendidikan karakter bukanlah proses pembelajaran yang menghafalkan konsep, teori dan dalil yang akan keluar dalam ujian akhir sekolah atau ujian akhir nasional serta teknik-teknik menjawabnya, akan tetapi merupakan pembiasaan-pembiasaan untuk berbuat baik, pembiasaan untuk berlaku jujur, kesatria, malu berbuat curang, malu bersikap malas, malu membiarkan lingkungannya kotor (Adiani dalam Suastika, 2017).

Karakter tidak terbentuk secara instan, tetapi harus dilatih dan dibiasakan secara berkesinambungan agar mencapai bentuk dan kekuatan yang ideal sebagai mana tujuan masyarakat, bangsa dan negara. Pembiasaan akan sangat baik dan berdaya guna bila dilakukan dari lingkungan, keluarga, sekolah dan masyarakat, bangsa dan negara. Dalam proses pendidikan, pembentukan karakter tidaklah dibebankan hanya pada satu atau dua mata pelajaran saja, akan tetapi diintegrasikan pada semua mata pelajaran.

\section{KESIMPULAN}

Secara historis cikal bakal berdirinya Bank Sampah Galang Panji berasal dari dua orang pemuda Dusun Kelod Kauh, Desa Panji, Kecamatan Sukasada yang bernama Gede Ganesha dan Nyoman Marsa Jaya. Keduanya bergabung dalam suatu organisasi pemuda pecinta lingkungan yakni Pemuda Peduli Lingkungan Bali (PPLB) yang berdiri pada tanggal 16 Agustus 2012. Melalui suatu refleksi, keberadaan mereka sebagai aktivis PLPB menimbulkan rasa malu karena desa mereka sendiri masih kotor dan belum bebeas dari sampah plastik. Akhirnya mereka menemukan solusi yang tepat untuk memecahkan permasalahan sampah di Desa Panji dengan cara mendirikan sebuah bank sampah. Pada awalnya mereka melakukan pendekatan dan sosialisasi kepada para pengurus dan anggota Sekaa Teruna Satya Warga, Banjar Kelod Kauh, Desa Panji, Kecamatan Sukasada. Berkat kegigihan mereka akhirnya program bank sampah mendapat dukungan dari para pemuda, perbekel Desa Panji, dan juga pemerintah Kabupaten Buleleng. Pada akhirnya pada bulan Oktober 2014 Bank Sampah yang diberi nama Bank Sampah Galang Panji berdiri secara resmi.

Bank Sampah Galang Panji dikelola oleh pengurus yang ditetapkan dengan Surat Keputusan Kepala Dinas Kebersihan dan Pertamanan Kabupaten Buleleng dan didukung oleh Surat Keputusan Perbekel Desa Panji. Kepengurusan Bank Sampah Galang Panji mencakup Donatur/Pelindung, Direktur/Ketua, Direktur Operasional yang dibantu oleh Koordinator Bidang Pengambilan, Koordinator Bidang Pemilahan, dan Koordinator Bidang Relawan, Direktur Keuangan, Staf Administrasi, dan Staf Kegiatan Pengembangan. Struktur Kepengurusan telah dimiliki oleh Bank Sampah Galang Panji. Direktur/Ketua Bank Sampah Galang Panji dijabat secara ex officio oleh Kepala Dusun Kelod Kauh dan Koordinator Bidang Relawan dijabat secara kolegial oleh Sekaa Teruna Satya Warga Banjar Adat Kelod Kauh, Desa Panji, Kecamatan Sukasada. Pengelolaan Bank Sampah Galang Panji sangat sederhana karena tidak memiliki deskripsi tugas, dewan pengawas, dan anggaran dasar dan anggaran rumah tangga.

Pengimplementasian Bank Sampah Galang Panji sebagai media pendidikan karakter dalam pembelajaran IPS di SMPN 4 Singaraja dilakukan secara terintegrasi. Strategi yang dapat dilakukan untuk pengimplemenntasian bank sampah sebagai media pendidikan karakter ada enam, yakni: (a) memanfaatkan media video pembelajaran tentang Bank Sampah Galang Panji dan dilanjutkan dengan diskusi atau tugas-tugas lain berkaitan dengan video tersebut; (b) memanfaatkan media foto tentang aktivitas para pemuda dalam menjalankan tugas mengelola Bank Sampah Galang Panji dan dilanjutkan dengan Focus Group Discussion tentang foto tersebut dikaitkan dengan karakter para pemuda tersebut; (c) mengundang narasumber salah seorang pemuda pendiri Bank Sampah Galang Panji untuk memberikan ceramah dan motivasi kepada para siswa di kelas; (d) para siswa diajak secara bersama-sama berkunjung ke lokasi Bank Sampah Galang Panji melalui metode karya wisata; (e) para siswa ditugaskansecara berkelompok membuat laporan kunjungan ke Bank Sampah Galang Panji; dan (f) secara berkelompok 
siswa diberi proyek membuat film dokumenter atau video tentang Bank Sampah Galang Panji. Menurut pendapat para guru dan siswa SMPN 4 Singaraja, dari keenam strategi tersebut strategi keempat yakni mengajak siswa berkunjung ke lokasi Bank Sampah Galang Panji merupakan strategi yang paling mudah dilakukan, paling menarik, memotivasi siswa untuk belajar, dan pembelajaran berpusat pada siswa. Selanjutnya, para guru dan siswa menyatakan bahwa strategi yang paling sulit diterapkan adalah strategi menugaskan siswa mengerjakan proyek pembuatan film dokumenter atau video tentang Bank Sampah Galang Panji.

\section{DAFTAR PUSTAKA}

Anggraini, Destilia, Mutiara Bunga Pertiwi, David Bahrin 2012. Pengaruh Jenis Sampah, Komposisi Masukan Dan Waktu Tinggal Terhadap Komposisi Biogas Dari Sampah Organik. Vol 18 No 1.

Asteria, Donna dan Heru Heruman. 2016. Bank Sampah Sebagai Alternatif Strategi Pengelolaan Sampah Berbasis Masyarakat Di Tasikmalaya. Jurnal Manusia dan Lingkungan. Vol 23 No 1. Hal 136-141.

Atikah, HR., 2013, Sistem Informasi Simpan Pinjam Pada Koperasi Wanita Putri Harapan Desa Jatigunung Kecamatan Tulakan, Indonesian. Journal on Networking and Security, Volume 2 No 4

Effendi, U. 2015. Asas Manajemen. Jakarta: Rajawali Pers.

Elmubarok, Z. 2009. Membumikan Pendidikan Nilai: Mengumpulkan yang Terserak, Menyambung yang Terputus, dan Menyatukan yang Tercerai. Bandung: Alfabeta.

Gibson, J. L., et al. 1996. Organisasi, Perilaku, Struktur, dan Proses. Alih Bahasa oleh Nunuk Andiarni, jilid 1 dan 2. Jakarta: Binarupa Aksara.

Hapsari, S dkk., 2012, Rancang Bangun Sistem Informasi Pembayaran Dan Tabungan Siswa Pada Bank Mini Artha Mandiri Sekolah Menengah Kejuruan (Smk) Negeri Pringkuku Pacitan, Indonesian.Jurnal on Computer Science Speed - FTI UNSA, Vol 9 No 3

Purwanto,Irwan, Dini Destiani, Partono. 2012. Perancangan Sistem Informasi Transaksi Tabungan Bank Sampah Garut. Jurnal STT-Garut All Right Reserved. Vol 9 No 31.

Riswan, Henna Rya Sunok, Agus Hadiyarto. 2011. Pengelolaan Sampah Rumah Tangga Di Kecamatan Daha Selatan. Jurnal Ilmu Lingkungan. Vol 9 No 1.

Riyanto, Andi Dwi dan Galuh Kusumastuti. 2015. Pembangunan Sistem Informasi Pengolahan Data Pada Tabungan Bank Sampah “Ceria” Purwokerto. Jurnal Telematika. Vol 8 No 2.

Soekanto, S. 1986. Talcott Parsons: Fungsionalisme Imperatif. Jakarta: CV Rajawali.

Suastika, I N. 2017. Memperkuat Pancasila sebagai Karakter Bangsa dalam Masyarakat Ekonomi ASEAN. Orasi Ilmiah disampaikan pada Dies Natalis Universitas Pendidikan Ganesha ke-24.

Subaris, H. dan Dwi Endah. 2016. Sedekah Sampah. Yogyakarta: Parama Publishing and Co.

Sukatman, dkk. 1998. Lingkungan Hidup untuk Sekolah Menengah Kejuruan. Malang: Indah Offset.

Sulistyorini, Lilis. 2005. Pengelolaan Sampah Dengan Cara Menjadikannya Kompos. Jurnal Kesehatan Lingkungan. Vol 2 No 2. Hal 77-84.

Wahyono, Sri. 2001. Pengolahan Sampah Organik Dan Aspek Sanitasi. Jurnal Teknologi Lingkungan. Vol 2 No 2. Hal 113-118.

Yuniwati,Murni, Frendy Iskarima, Adiningsih Padulemba. 2012. Optimasi Kondisi Proses Pembuatan Kompos Dari Sampah Organik Dengan Cara Fermentasi Menggunakan EM4. Vol 5 No 2. Hal 172181.

Zubaedi. 2013. Desain Pendidikan Karakter. Jakarta: Kencana Prenada Media Group. 